\title{
Effect of zinc oxide nanoparticles synthesized by a precipitation method on mechanical and morphological properties of the CR foam
}

\author{
RUDEERAT SUNTAKO* \\ Department of Physics, Faculty of Liberal Arts and Science, Kasetsart University, Kamphaeng Saen Campus, \\ Nakhon Pathom 73140, Thailand
}

MS received 27 November 2014; accepted 8 January 2015

\begin{abstract}
ZnO nanoparticles were synthesized by a precipitation method in aqueous media from zinc nitrate hexahydrate and sodium hydroxide. The synthesized $\mathrm{ZnO}$ nanoparticles exhibited a crystalline structure with hexagonal structure of the wurtzite. The morphology of the synthesized $\mathrm{ZnO}$ nanoparticles presented a spherical shape with the average primary size of $54.53 \mathrm{~nm}$ and the specific surface area of $20.28 \mathrm{~m}^{2} \mathrm{~g}^{-1}$. The effect of the synthesized ZnO nanoparticles by the precipitation method as a crosslinking agent for chloroprene rubber foam (CR foam) on cure characteristics, mechanical properties and morphologies was investigated. The aim of this study is to vary the synthesized $\mathrm{ZnO}$ nanoparticles' level in the range of 0.5-5 parts per hundred parts of rubber (phr) compared with the conventional $\mathrm{ZnO}$ at $5 \mathrm{phr}$. The rheological characterization showed that the maximum torque $\left(M_{\mathrm{H}}\right)$, the minimum torque $\left(M_{\mathbf{L}}\right)$, the differential torque $\left(M_{\mathbf{H}}-M_{\mathbf{L}}\right)$ and Mooney viscosity increased with the increase in synthesized ZnO nanoparticles' content, whereas the optimum cure time (t90) and scorch time (T5) decreased. On the other hand, the mechanical properties such as hardness, tensile strength and specific gravity were improved. For CR foam, the results compared to the amount of conventional $\mathrm{ZnO}$, only $60 \mathrm{wt} \%(3 \mathrm{phr})$ nano-ZnO was enough to obtain similar cure characteristics and mechanical properties. The synthesized $\mathrm{ZnO}$ nanoparticles showed the mechanical properties higher than conventional $\mathrm{ZnO}$ because of small particle size and large specific surface area which led to the increase in the degree of crosslinking.
\end{abstract}

Keywords. Zinc oxide; nanoparticles; synthesis; chloroprene rubber; CR foam.

\section{Introduction}

Zinc oxide $(\mathrm{ZnO})$ has attracted much attention because of its interest in basic study and its application aspects such as rubber, ceramics, electronics, paints, animal feed, cosmetics and pharmaceuticals. ${ }^{1-3}$ In recent times, many applications need $\mathrm{ZnO}$ nanoparticles for high-quality products which include controlled processing from synthesis, forming and sintering. However, the synthesis of $\mathrm{ZnO}$ nanoparticles remains a challenge. Many methods for synthesis of $\mathrm{ZnO}$ nanoparticles have been reported in wet chemistry such as thermal decomposition, ${ }^{4}$ sol-gel techniques ${ }^{5}$ and precipitation. ${ }^{6}$ Precipitation is one of the methods which can control the size, shape and morphology of particles at low temperature. Advantages of the aqueous precipitation method compared with other methods are low cost, simplicity and nontoxicity. Precipitate can be formed as nuclei and then nuclei grows to become particles. ${ }^{7}$ Nuclei formation and growth of nuclei depend on the concentration of precursor solution and reactive time. ${ }^{8}$ The precipitation method can control different parameters such as solution concentration and pH. ${ }^{9,10}$ The synthesis of $\mathrm{ZnO}$ nanoparticles by the precipitation method involves the reaction of zinc salts such as $\mathrm{Zn}\left(\mathrm{NO}_{3}\right)_{2}, \mathrm{Zn}\left(\mathrm{CH}_{3} \mathrm{COO}\right)_{2} \cdot 2 \mathrm{H}_{2} \mathrm{O}$ and $\mathrm{ZnSO}_{4}$ with basic

\footnotetext{
*Author for correspondence (rudeerat_p@ hotmail.com)
}

solutions containing $\mathrm{LiOH}, \mathrm{NH}_{4} \mathrm{OH}$ and $\mathrm{NaOH}^{3,11,12}$ Kumar et $\mathrm{al}^{13}$ synthesized $\mathrm{ZnO}$ nanoparticles by the precipitation method from zinc sulphate heptahydrate and sodium hydrate as precursors. In rubber industry $\mathrm{ZnO}$ is used as an activator of rubber vulcanization. $\mathrm{ZnO}$ is important as it affects the vulcanization rate and properties of rubber products. Commonly, the conventional rubber grade uses $\mathrm{ZnO}$ particle size in the range of $0.1-0.4 \mu \mathrm{m}$ and the specific surface area of around $10-20 \mathrm{~m}^{2} \mathrm{~g}^{-1} \cdot 14,15$ The tendency is to minimize the amount of $\mathrm{ZnO}$ in rubber compound because of its toxicity. Control of $\mathrm{ZnO}$ as activator is related to processing and properties of rubber. However, we expected that $\mathrm{ZnO}$ nanoparticles can reduce the amount of $\mathrm{ZnO}$ usage as activator. Kim et $\mathrm{al}^{15}$ studied the effect of $\mathrm{ZnO}$ nanoparticles on the cure characteristics and mechanical properties of the silicafilled natural rubber/butadiene rubber compounds. With the increasing amount of $\mathrm{ZnO}$ nanoparticles, the cure characteristics and mechanical properties are increased. This is due to the increase in specific surface area of $\mathrm{ZnO}$ nanoparticles which leads to increase in the degree of crosslinking.

Chloroprene rubber $(\mathrm{CR})$ is a polar rubber and contains chlorine atom attached to the backbone. Therefore, it has ozone and weather resistance, mineral and vegetable oil resistance and low flammability when compared with nonpolar rubbers such as natural rubber (NR), ethylene propylene diene monomer (EPDM), etc. Chloroprene rubber is 
vulcanized by metal oxides. The metal oxides often use $\mathrm{ZnO}$ as crosslinking agent with magnesium oxide $(\mathrm{MgO})$, which is used as an acid acceptor. Generally, the conventional $\mathrm{ZnO}$ is used in chloroprene rubber formulation at $5 \mathrm{phr}$ with magnesium oxide at $4 \mathrm{phr}$ for the optimum cure state. The nanotechnology may be able to reduce the amount of usage of $\mathrm{ZnO}$ due to the decrease in particle size and increase of specific surface area. CR foam is produced with a blowing agent to create an air-filled matrix structure which is used in the automotive industry as well as in air conditioning fields. It is used for sealing, isolating, confinement and shock absorption.

In this study, $\mathrm{ZnO}$ nanoparticles are synthesized by the precipitation method using zinc nitrate hexahydrate and sodium hydroxide as precursors. The synthesized $\mathrm{ZnO}$ nanoparticles are characterized by X-ray diffraction (XRD), Fourier transform infrared spectroscopy (FTIR) and scanning electron microscopy (SEM). The specific surface area and particle size distribution are investigated by the BrunauerEmmett-Teller (BET) and laser light scattering technique. Later, CR foam is prepared at various synthesized $\mathrm{ZnO}$ nanoparticles' levels in the range of $0.5-5$ parts per hundred parts of rubber (phr) compared with the conventional $\mathrm{ZnO}$ at $5 \mathrm{phr}$. The influences of synthesized $\mathrm{ZnO}$ nanoparticles' content on the cure characteristics, Mooney viscosity and mechanical properties of the foam are investigated. Furthermore, a microscopic study is also performed to study the effect of the synthesized $\mathrm{ZnO}$ nanoparticles' content on the morphology of the CR foam.

\section{Experimental}

\subsection{Synthesis of $\mathrm{ZnO}$ nanoparticles}

$\mathrm{ZnO}$ nanoparticles were synthesized by the precipitation method using zinc nitrate hexahydrate $\left(\mathrm{Zn}\left(\mathrm{NO}_{3}\right)_{2} \cdot 6 \mathrm{H}_{2} \mathrm{O}\right.$, Qrec) and sodium hydroxide $(\mathrm{NaOH}$, Qrec) as precursors. $\mathrm{ZnO}$ nanoparticles were produced by mixing aqueous solutions of zinc nitrate and sodium hydrate. $\mathrm{ZnO}$ nanoparticles were formed by the reaction between $\mathrm{Zn}^{2+}$ and hydroxide ions as shown by the following equations: ${ }^{11}$

$$
\begin{aligned}
& \mathrm{Zn}\left(\mathrm{NO}_{3}\right)_{2} \rightarrow \mathrm{Zn}^{2+}+2 \mathrm{NO}_{3}^{-}, \\
& \mathrm{Zn}^{2+}+2 \mathrm{OH}^{-} \rightarrow \mathrm{Zn}(\mathrm{OH})_{2}, \\
& \mathrm{Zn}(\mathrm{OH})_{2} \rightarrow \mathrm{ZnO}+\mathrm{H}_{2} \mathrm{O} .
\end{aligned}
$$

The aqueous solution was prepared by mixing zinc nitrate hexahydrate and sodium hydroxide aqueous solutions. In a typical procedure, $2.28 \mathrm{~g}$ of zinc nitrate hexahydrate was dissolved in $75 \mathrm{ml}$ of deionized water and then, $0.6 \mathrm{~g}$ of $\mathrm{NaOH}$ in $150 \mathrm{ml}$ of deionized water was added dropwise under magnetic stirring. After the addition was completed, the stirring was continued for $30 \mathrm{~min}$ and then cooled with cold water. The precipitates were filtered and washed by pure water several times. Then the obtained precipitates were dried at $60^{\circ} \mathrm{C}$ for $24 \mathrm{~h}$ and calcined at $200^{\circ} \mathrm{C}$ for $2 \mathrm{~h}$. The crystalline and phase structure of the synthesized $\mathrm{ZnO}$ was studied by an $\mathrm{X}$-ray diffractometer (XRD, D8-Advance, Bruker, $\mathrm{CuK} \alpha$ radiation). FTIR spectra were studied in the range of $400-4000 \mathrm{~cm}^{-1}$. Morphology and primary sizes of the synthesized $\mathrm{ZnO}$ were observed by a SEM (JSM-5410LV, JEOL). The specific surface areas were investigated by the Brunauer-EmmettTeller (BET) technique. The particle size distribution was measured by a laser light scattering technique (Mastersizer 2000, Malvern Instruments). Morphology, particle size and specific surface area of the conventional $\mathrm{ZnO}$ were studied by SEM, BET and laser light scattering techniques, respectively.

\subsection{Preparation of the CR foam}

Formulation of the CR foam is shown in table 1. Compound was prepared in an internal mixer of 3 litre (fill factor 0.75 and rotor speed $30 \mathrm{rpm}$ ). The accelerator, blowing

\begin{tabular}{|c|c|c|c|c|c|c|}
\hline Materials & $\mathrm{cZnO}-5 \mathrm{phr}$ & $\mathrm{nZnO}-0.5 \mathrm{phr}$ & $\mathrm{nZnO}-1 \mathrm{phr}$ & $\mathrm{nZnO}-2 \mathrm{phr}$ & nZnO-3 phr & $\mathrm{nZnO}-5 \mathrm{phr}$ \\
\hline Chloroprene rubber & 100 & 100 & 100 & 100 & 100 & 100 \\
\hline Carbon black (N-774) & 60 & 60 & 60 & 60 & 60 & 60 \\
\hline $\mathrm{CaCO}_{3}$ & 30 & 30 & 30 & 30 & 30 & 30 \\
\hline Naphthenic oil & 25 & 25 & 25 & 25 & 25 & 25 \\
\hline Stearic acid & 1 & 1 & 1 & 1 & 1 & 1 \\
\hline $\mathrm{MgO}$ & 4 & 4 & 4 & 4 & 4 & 4 \\
\hline Conventional $\mathrm{ZnO}$ & 5 & - & - & - & - & - \\
\hline $\mathrm{ZnO}$ nanoparticles & - & 0.5 & 1 & 2 & 3 & 5 \\
\hline Q-25 & 7 & 7 & 7 & 7 & 7 & 7 \\
\hline OBSH-75 & 3 & 3 & 3 & 3 & 3 & 3 \\
\hline ZDEC & 1 & 1 & 1 & 1 & 1 & 1 \\
\hline TRA & 0.8 & 0.8 & 0.8 & 0.8 & 0.8 & 0.8 \\
\hline DETU-80 & 1 & 1 & 1 & 1 & 1 & 1 \\
\hline
\end{tabular}
agent and curing agent were added on a two roll mill at

Table 1. Formulation of the CR foam. 


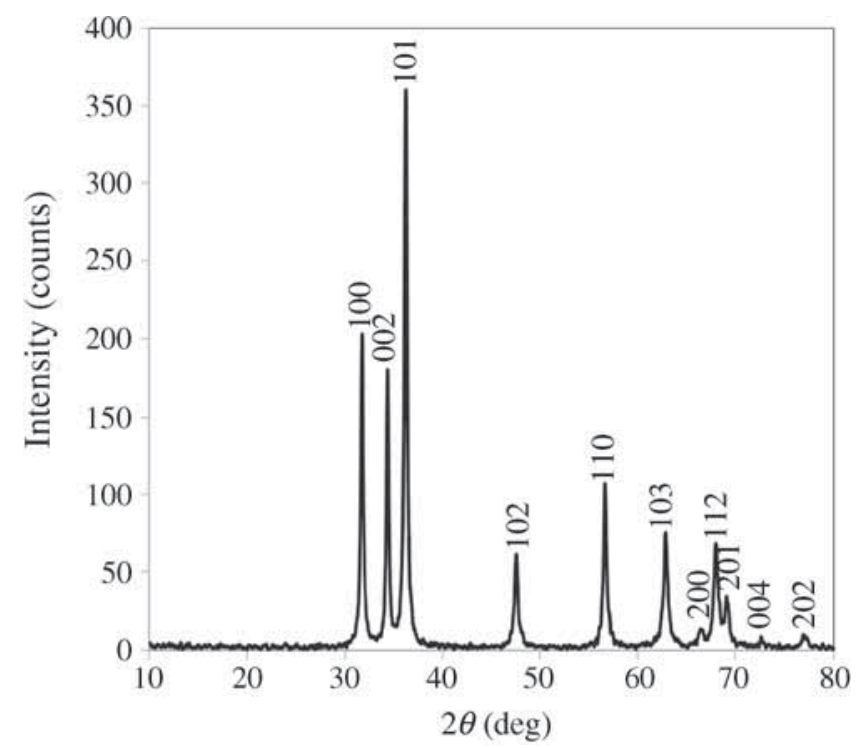

Figure 1. XRD pattern of the synthesized $\mathrm{ZnO}$ nanoparticles.

room temperature $\left(35^{\circ} \mathrm{C}\right)$ and sheeted off to a thickness of $8 \mathrm{~mm}$.

\subsection{Characterization of the CR foam}

The cure characteristics of the CR foam were measured at $200^{\circ} \mathrm{C}$ for $10 \mathrm{~min}$ with a Moving Die Rheometer (MDR2000, Alpha Technologies). The maximum torque $\left(M_{\mathrm{H}}\right)$, the minimum torque $\left(M_{\mathrm{L}}\right)$, the differential torque $\left(M_{\mathrm{H}}-M_{\mathrm{L}}\right)$ and the optimum cure time $\left(t_{90}\right)$ were determined. Mooney viscosity $(\mathrm{ML1}+4)$ and scorch time $(T 5)$ were measured at $125^{\circ} \mathrm{C}$ for 6 min by a Mooney viscometer (MV2000, Alpha Technologies). Morphology of the CR foam was observed for the cell structure by a digital microscope (VHX-500F-Lens 450X, Keyence). The hardness test was performed using hardness tester (Teclock). The specimen was prepared by compression moulding at $165^{\circ} \mathrm{C}$ for $5 \mathrm{~min}$ (pre-vulcanization) and curing and foaming in air oven at $160^{\circ} \mathrm{C}$ for $30 \mathrm{~min}$. Hardness scale was measured within $30 \mathrm{~s}$ after the full load was applied. The specific gravity of the CR foam was measured in accordance with ISO 1183. Finally, the tensile strength of the samples was measured using an autograph (AG-IS, Shimadzu) at a cross-head speed of $50 \mathrm{~mm} \mathrm{~min}^{-1}$ at $25 \pm 5^{\circ} \mathrm{C}$.

\section{Results and discussion}

\subsection{Characteristics of the synthesized ZnO nanoparticles}

The XRD pattern of the synthesized $\mathrm{ZnO}$ nanoparticles is shown in figure 1. The crystalline structure of synthesized $\mathrm{ZnO}$ nanoparticles exhibited a hexagonal structure of the wurtzite (JCPDS no. 36-1451). These planes correspond to (100), (002), (101), (102), (110), (103), (200), (112), (201), (004) and (202). ${ }^{16}$ The average crystalline size of the synthesized $\mathrm{ZnO}$ was determined using Debye-Scherrer's

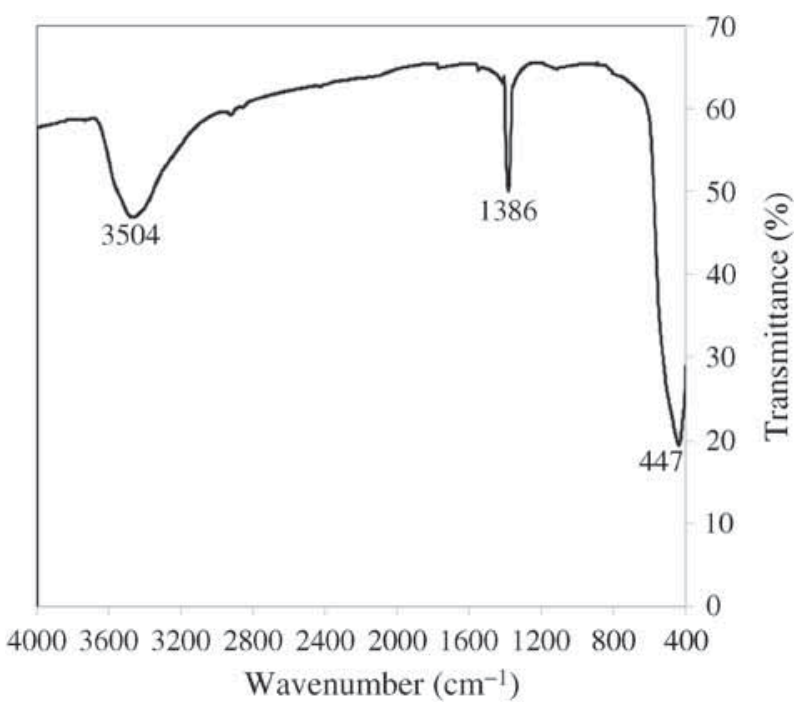

Figure 2. FTIR spectra of the synthesized $\mathrm{ZnO}$ nanoparticles.
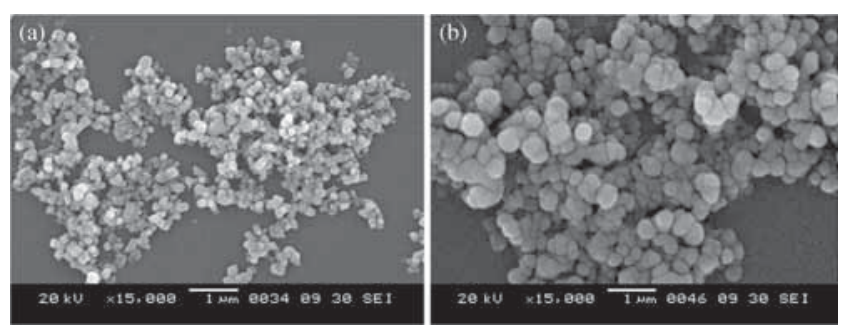

Figure 3. SEM images of $\mathrm{ZnO}$ particles (a) the synthesized $\mathrm{ZnO}$ nanoparticles and (b) the conventional $\mathrm{ZnO}$.

formula. ${ }^{7}$ The crystalline size analysis investigated from the highly intense and sharp diffraction peak corresponds to the (101) diffraction by the following equation:

$$
\langle D\rangle=\frac{0.9 \lambda}{\beta \cos \theta},
$$

where $\langle D\rangle$ is the average crystalline size, $\lambda$ the $\mathrm{CuK} \alpha$ radiation wavelength, i.e., $1.5414 \AA$, $\beta$ the full-width at halfmaximum in radians and $\theta$ the scattering angle in degree. The average crystalline size of the synthesized $\mathrm{ZnO}$ is $51.23 \mathrm{~nm}$.

Figure 2 shows the FTIR spectra of the synthesized $\mathrm{ZnO}$ nanoparticles in the range of $4000-400 \mathrm{~cm}^{-1}$. The broad band at $3504 \mathrm{~cm}^{-1}$ is the stretching vibration of $\mathrm{O}-\mathrm{H}$ group. The peak at $1386 \mathrm{~cm}^{-1}$ is due to the $\mathrm{O}-\mathrm{H}$ bending of water. The peak at $447 \mathrm{~cm}^{-1}$ is attributed to the $\mathrm{Zn}-\mathrm{O}$ stretching of vibration which is consistent with the previously reported work. ${ }^{11}$

The SEM images of $\mathrm{ZnO}$ particles are shown in figure 3. The morphology of the synthesized $\mathrm{ZnO}$ nanoparticles is presented as a spherical shape with the average primary size of $54.35 \mathrm{~nm}$ (figure 3a). It was confirmed by DebyeScherrer's formula that the morphology of the conventional $\mathrm{ZnO}$ showed a spherical shape with the average primary size of $218.98 \mathrm{~nm}$ in figure $3 \mathrm{~b}$. Table 2 shows the particle size and the specific surface area of the synthesized $\mathrm{ZnO}$ nanoparticles and the conventional $\mathrm{ZnO}$. 
Table 2. Average particle size and the specific surface area of $\mathrm{ZnO}$ particles.

\begin{tabular}{lcc}
\hline Samples & $\begin{array}{c}\text { Particle } \\
\text { sizes }(\mathrm{nm})\end{array}$ & $\begin{array}{c}\text { Specific surface } \\
\text { area }\left(\mathrm{m}^{2} \mathrm{~g}^{-1}\right)\end{array}$ \\
\hline Synthesized ZnO nanoparticles & 54.53 & 20.28 \\
Conventional ZnO & 218.98 & 1.33 \\
\hline
\end{tabular}

Figure 4 shows particle size distribution of the synthesized $\mathrm{ZnO}$ nanoparticles and the conventional $\mathrm{ZnO}$ using laser light scattering technique. The synthesized $\mathrm{ZnO}$ nanoparticles showed particle size distribution of agglomerate nanoparticles. Most of the agglomerate sizes were in the range of $0.2-5 \mu \mathrm{m}$ and some agglomerates around $20 \mu \mathrm{m}$. For the conventional $\mathrm{ZnO}$, it showed the particle size distribution with agglomerated particles. Most of agglomerate sizes were in the range of $1.5-55 \mu \mathrm{m}$ and some particles were in the range of $0.3-1.2 \mu \mathrm{m}$. The median particle size of the synthesized $\mathrm{ZnO}$ nanoparticles and the conventional $\mathrm{ZnO}$ was 2.39 and $7.00 \mu \mathrm{m}$, respectively.

\subsection{Cure characteristics and Mooney viscosity of the CR foam}

The cure characteristics of the CR foam were measured by a Moving Die Rheometer (MDR2000) and Mooney viscosity was measured by a Mooney viscometer (MV2000) in which variation of synthesized $\mathrm{ZnO}$ nanoparticles' level in the range of $0.5-5$ parts per hundred parts of rubber (phr) was compared with conventional $\mathrm{ZnO} 5 \mathrm{phr}$ because of small particle size and large specific surface area. The test results showed that the maximum torque $\left(M_{\mathrm{H}}\right)$, the minimum torque $\left(M_{\mathrm{L}}\right)$ and the differential torque $\left(M_{\mathrm{H}}-M_{\mathrm{L}}\right)$ were slightly increased with increasing synthesized $\mathrm{ZnO}$ nanoparticles' content, listed in table 3, indicating a higher degree of crosslink density in compound.

It was widely known that the differential torque $\left(M_{\mathrm{H}}-M_{\mathrm{L}}\right)$ was directly related to the cure state or crosslink concentration of a network in compound. ${ }^{17-19}$ The synthesized $\mathrm{ZnO}$ nanoparticles were often used as a curing agent with magnesium oxide $(\mathrm{MgO})$ for vulcanization. It reacted with rubber molecular chain creating ether bond so as to completely crosslink in rubber as shown in figure $5 .^{20} \mathrm{~A}$ decreasing trend of the optimum cure time $\left(t_{90}\right)$ and scorch time $(T 5)$

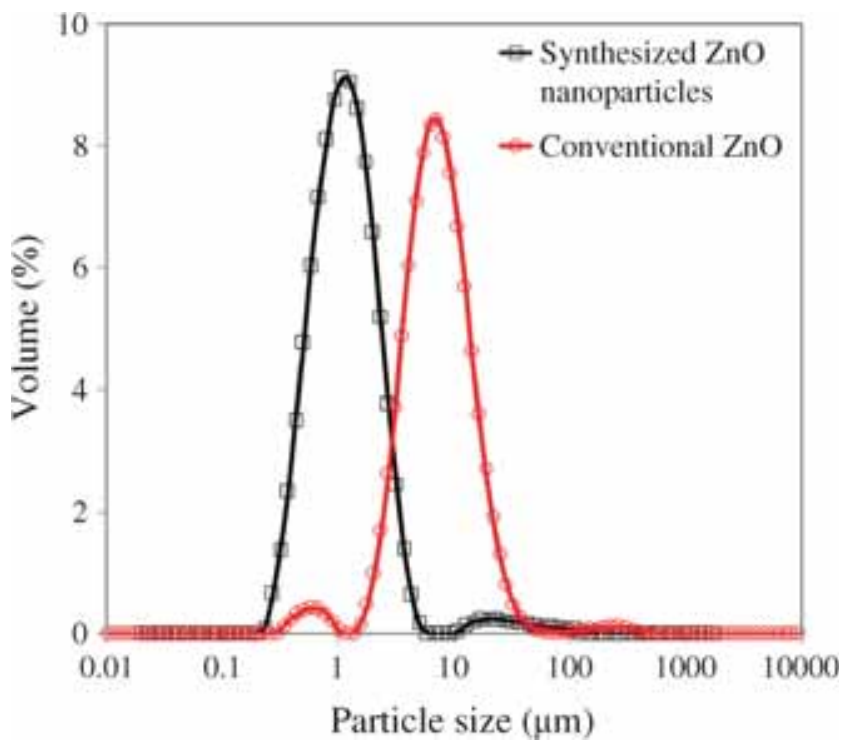

Figure 4. Particle size distribution of the synthesized $\mathrm{ZnO}$ nanoparticles and the conventional $\mathrm{ZnO}$.

varied with the increase of the synthesized $\mathrm{ZnO}$ nanoparticles' content. This may be attributed to the $\mathrm{ZnCl}_{2}$ formation in rubber vulcanization, which acts as a catalyst of vulcanization and accelerates the curing rate reaction. Furthermore, the increase of Mooney viscosity (ML1 + 4) was brought about by the increase in the synthesized $\mathrm{ZnO}$ nanoparticles' content because of faster scorch time (T5). Hence, at the $3 \mathrm{phr}$ of the synthesized $\mathrm{ZnO}$ nanoparticles showed that the cure characteristics and Mooney viscosity were equivalent with the conventional $\mathrm{ZnO}$ at $5 \mathrm{phr}$, which indicate that it is similar to that of the cure state of rubber compound. The synthesized $\mathrm{ZnO}$ nanoparticles at $5 \mathrm{phr}$ showed the highest degree of crosslink density in compound because of the highest differential torque $\left(M_{\mathrm{H}}-M_{\mathrm{L}}\right)$.

\subsection{Mechanical properties of the CR foam}

The effect of the synthesized $\mathrm{ZnO}$ nanoparticles' content on the hardness and specific gravity of the CR foam is presented in figure 6. It was observed that the specific gravity of the CR foam gradually increased with the increase in the synthesized $\mathrm{ZnO}$ nanoparticles' content. This observation may be attributed to the decrease in foaming efficiency of rubber foam because of lower scorch time (T5). A

Table 3. Cure characteristics and Mooney viscosity of the CR foam.

\begin{tabular}{|c|c|c|c|c|c|c|}
\hline Cure characteristics & $\mathrm{cZnO}-5 \mathrm{phr}$ & $\mathrm{nZnO}-0.5 \mathrm{phr}$ & $\mathrm{nZnO}-1 \mathrm{phr}$ & $\mathrm{nZnO}-2 \mathrm{phr}$ & $\mathrm{nZnO}-3 \mathrm{phr}$ & $\mathrm{nZnO}-5 \mathrm{phr}$ \\
\hline The maximum torque $\left(M_{\mathrm{H}}\right), \mathrm{lb}$ in & 8.84 & 7.59 & 7.88 & 7.92 & 8.77 & 9.15 \\
\hline The minimum torque $\left(M_{\mathrm{L}}\right), \mathrm{lb}$ in & 0.77 & 0.74 & 0.78 & 0.79 & 0.85 & 0.86 \\
\hline The differential torque $\left(M_{\mathrm{H}}-M_{\mathrm{L}}\right), \mathrm{lb}$ in & 8.07 & 6.85 & 7.10 & 7.13 & 7.92 & 8.29 \\
\hline The optimum cure time $\left(t_{90}\right), \mathrm{min}$ & 3.45 & 4.32 & 4.19 & 3.86 & 3.51 & 3.32 \\
\hline Mooney viscosity $\left(\mathrm{ML} 1+4\right.$ at $\left.125^{\circ} \mathrm{C}\right)$, MU & 31.48 & 26.17 & 28.97 & 31.22 & 32.50 & 33.12 \\
\hline Scorch time $(T 5), \min$ & 5.00 & 6.78 & 5.77 & 5.29 & 5.08 & 4.82 \\
\hline
\end{tabular}




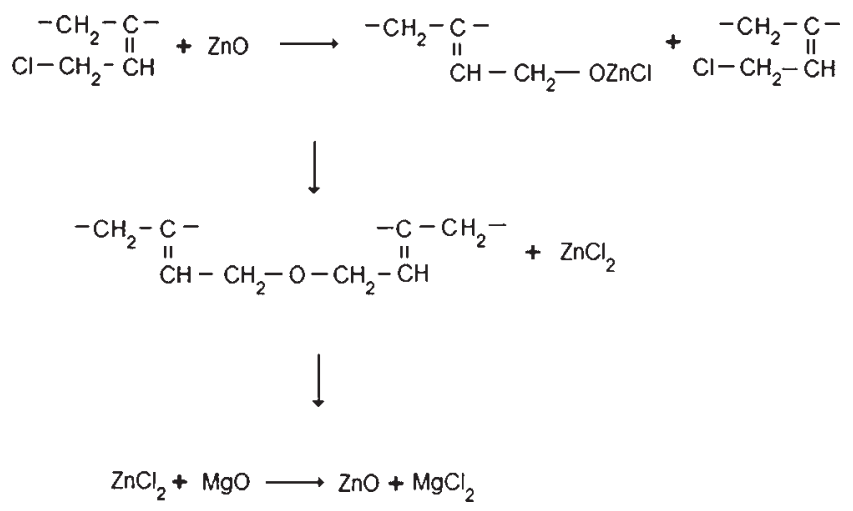

Figure 5. Mechanism of crosslinking by metal oxide.

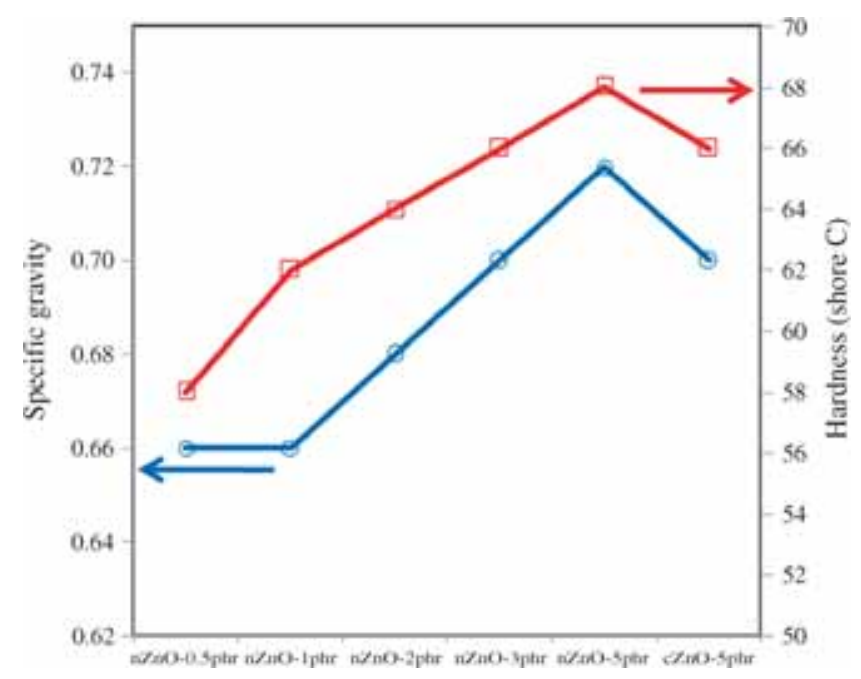

Figure 6. Specific gravity and hardness of the CR foam with various synthesized $\mathrm{ZnO}$ nanoparticles' content compared with conventional $\mathrm{ZnO}$.

decreasing trend in scorch time (T5) with the increased synthesized $\mathrm{ZnO}$ nanoparticles' content in compound showed the low foam porosity and exhibited more rigid behaviour than the elastic behaviour, as later explained by a digital microscope. This result also corresponded to hardness of the rubber foam, which was similar to the result obtained for the specific gravity. It was obvious that the hardness and specific gravity directly corresponded to the particle size, specific surface area and amount of the synthesized $\mathrm{ZnO}$ nanoparticles. On the other hand, the tensile strength was also investigated with respect to the synthesized $\mathrm{ZnO}$ nanoparticles' content, as shown in figure 7 . The tensile strength continuously increased with the increase in the synthesized $\mathrm{ZnO}$ nanoparticles' content. This observation is due to the reinforcement of crosslinking density which was affected by the increase of the differential torque $\left(M_{\mathrm{H}}-M_{\mathrm{L}}\right)$, as previously mentioned in table 3. Moreover, the CR foam also showed the lowest foaming capability and exhibited better tensile properties. ${ }^{21}$ From all the results mentioned above, the synthesized $\mathrm{ZnO}$ nanoparticles could be successfully reduced from 5 to $3 \mathrm{phr}$

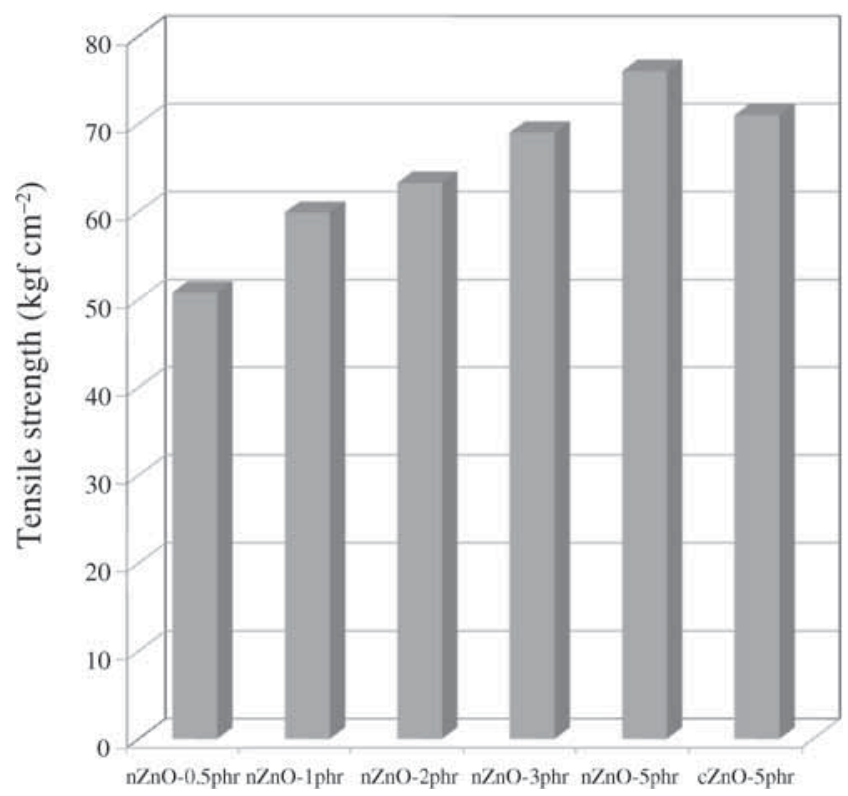

Figure 7. Tensile strength of the CR foam with various synthesized $\mathrm{ZnO}$ nanoparticles' content compared with conventional $\mathrm{ZnO}$.
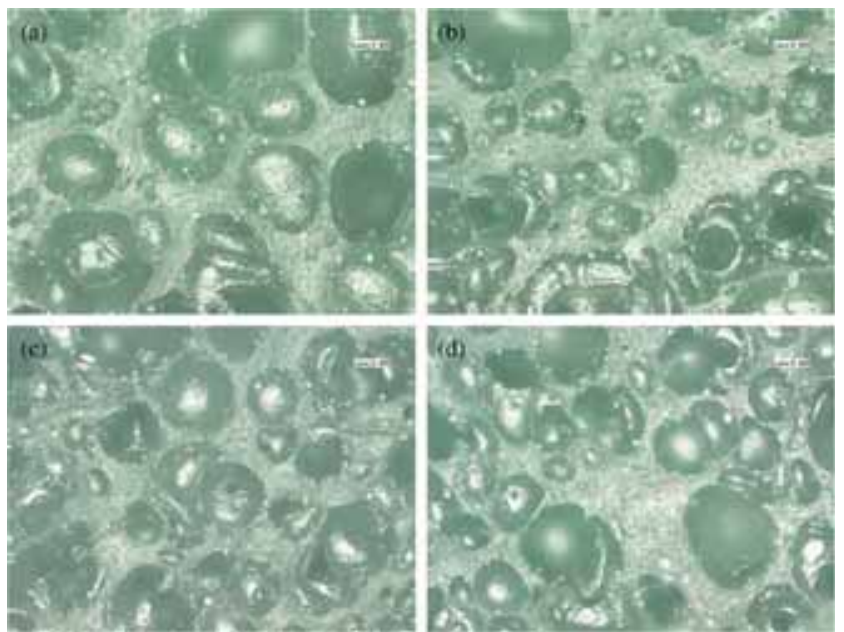

Figure 8. Morphology of the CR foam using (a) the synthesized $\mathrm{ZnO}$ nanoparticles at $1 \mathrm{phr}$, (b) the synthesized $\mathrm{ZnO}$ nanoparticles at $3 \mathrm{phr}$, (c) the synthesized $\mathrm{ZnO}$ nanoparticles at $5 \mathrm{phr}$ and (d) the conventional $\mathrm{ZnO}$ at $5 \mathrm{phr}$.

because the particle sizes of $\mathrm{ZnO}$ are decreased, whereas, the specific surface area is increased. Moreover, it could be seen that the synthesized $\mathrm{ZnO}$ nanoparticles at $5 \mathrm{phr}$ showed the highest mechanical properties.

\subsection{Morphological property of the CR foam}

The influence of the synthesized $\mathrm{ZnO}$ nanoparticles' content on the morphology and foam characteristics of the CR foam was evaluated by a digital microscope with 450 magnifications as illustrated in figure 8 . The experimental result 
showed that the cell size of the CR foam decreased with the increase in the synthesized $\mathrm{ZnO}$ nanoparticles' content. Moreover, the cell structure of the CR foam was a spherulite structure. This phenomenon was due to a decreasing trend of scorch time (T5) where the low expansion and foam porosity during the vulcanization process are affected. The cell morphology showed that the cell size of the CR foam directly corresponded to foam porosity and exhibited a closed cell structure because air was not free to pass through the cell. ${ }^{22}$ It could be seen that cell structure of the CR foam at $5 \mathrm{phr}$ of the conventional $\mathrm{ZnO}$ was similar to the cell size at $3 \mathrm{phr}$ of the synthesized $\mathrm{ZnO}$ nanoparticles.

\section{Conclusions}

$\mathrm{ZnO}$ nanoparticles were synthesized by the precipitation method in an aqueous media from zinc nitrate hexahydrate and sodium hydroxide as precursors. The crystalline structure of the synthesized $\mathrm{ZnO}$ nanoparticles exhibited a hexagonal structure of wurtzite. TEM micrograph of the synthesized $\mathrm{ZnO}$ provided a spherical shape with the average primary size of $54.53 \mathrm{~nm}$ and the specific surface area of $20.28 \mathrm{~m}^{2} \mathrm{~g}^{-1}$. The synthesized $\mathrm{ZnO}$ nanoparticles were used as a crosslinking agent compared with the conventional $\mathrm{ZnO}$ for the $\mathrm{CR}$ foam.

1. The maximum torque $\left(M_{\mathrm{H}}\right)$, the minimum torque $\left(M_{\mathrm{L}}\right)$, the differential torque $\left(M_{\mathrm{H}}-M_{\mathrm{L}}\right)$ and Mooney viscosity are increased with the increase in the synthesized $\mathrm{ZnO}$ nanoparticles' content.

2. The optimum cure time ( $\left.t_{90}\right)$ and Mooney scorch (T5) are decreased with the increase in the synthesized $\mathrm{ZnO}$ nanoparticles' content.

3. The hardness, tensile strength and specific gravity are increased with the increasing synthesized $\mathrm{ZnO}$ nanoparticles' content.

4. The cell size of the $\mathrm{CR}$ foam decreased with the increase in the synthesized $\mathrm{ZnO}$ nanoparticles.

5. For CR foam, the results compared to the amount of conventional $\mathrm{ZnO}$ at $5 \mathrm{phr}$, only a $60 \mathrm{wt} \%$ ( $3 \mathrm{phr}$ ) nano$\mathrm{ZnO}$ was enough to obtain similar cure characteristics and mechanical properties.

6. The synthesized $\mathrm{ZnO}$ nanoparticles showed the mechanical properties higher than conventional $\mathrm{ZnO}$ because of the smaller particle size and larger specific surface area.

\section{Acknowledgements}

I gratefully acknowledge the financial support from the Research Promotion and Technology Transfer Center (RPTTC), Faculty of Liberal Arts and Science, Kasetsart University Kamphaeng Saen Campus and the Kasetsart University Research and Development Institute (KURDI).

\section{References}

1. Suntako R 2014 Adv. Mater. Res. 1025-1026 525

2. Aimable A, Buscaglia M T, Buscaglia V and Bowen P 2010 J. Eur. Ceram. Soc. 30591

3. Faure B, Alvarez G S, Ahniyaz A, Villaluenga I, Berriozabal G, Miguel Y D and Bergstrom L 2013 Sci. Technol. Adv. Mater. 141

4. Baskoutas S, Giabouranis P, Yannopoulos S N, Dracopoulos V, Toth L, Chrissanthopoulos A and Bouropoulos N 2007 Thin Solid Films $\mathbf{5 1 5} 8461$

5. Rani S, Suri P, Shishodia P K and Mehra R M 2008 Sol. Energy Mater. Sol. C 921639

6. Suntako R 2014 Adv. Mater. Res. 1044-1045 23

7. Sangari N U and Devi S C 2013 J. Solid State Chem. 197483

8. Sharma D, Rajput J, Kaith B S, Kaur M and Sharma S 2010 Thin Solid Films 5191224

9. Suntako R 2014 Appl. Mech. Mater. 48160

10. Raoufi D 2013 Renew. Energy 50932

11. Nejati K, Rezvani $Z$ and Pakizevand R 2011 Int. Nano Lett. 175

12. Skapin S D, Drazic G and Orel Z C 2007 Mater. Lett. 612783

13. Kumar S S, Venkateswarlu P, Rao V R and Rao G N 2013 Int. Nano Lett. 330

14. Sahoo S, Maiti M, Ganguly A, George J J and Bhowmick A K 2007 J. Appl. Polym. Sci. 1052407

15. Kim I J, Kim W S, Lee D H, Kim W and Bae J W 2010 J. Appl. Polym. Sci. 1171535

16. Wang H, Li C, Zhao H, Li R and Liu J 2013 Powder Technol. 239266

17. Akhlaghi S, Kalaee M, Mazinani S, Jowdar E, Nouri A, Sharif A and Sedaghat N 2012 Thermochim. Acta 52791

18. Przybyszewska M, Zaborski M, Jakubowski B and Zawadiak J 2009 Express Polym. Lett. 3256

19. Tang M Z, Xing W, Wu J R, Huang G S, Li H and Wu S D 2014 Chin. J. Polym. Sci. 32658

20. Scott J C, White G D F, Thom D J, Whitny R A and Hopkins W 2003 J. Polym. Sci. Part A 411915

21. Kim J H, Choi K C and Yoon J M 2006 J. Ind. Eng. Chem. 12795

22. Zhang B S, Lv X F, Zhang Z X, Liu Y, Kim J K and Xin Z X 2010 Mater. Des. 313106 